\title{
References and further reading
}

Adcock, R., and D. Collier. 2001. Measurement Validity: A Shared Standard for Qualitative and Quantitative Research. American Political Science Review, 95:3, pp. 529-46.

Afonso, A. 2017. Challenges for the Dutch Polder Model: Performance, Populism and Political Economy. Beleid en Maatschappij, 44:1, 70-5.

Ainsworth, Scott H. 1997. The Role of Legislators in the Determination of Interest Group Influence. Legislative Studies Quarterly, 22:4, pp. 517-33.

Ainsworth, Scott H. 1993. Regulating Lobbyists and Interest Group Influence, Journal of Politics, 55:1, pp. 41-56.

Almond, Gabriel A. 1956. Comparing Political Systems. Journal of Politics,18:2, pp. 391-409.

ALTER-EU. 2013. ALTER-EU Briefing on the review process of the Transparency Register. Available at: www.alter-eu.org/sites/default/files/documents/ALTER-EU _Briefing_\%20Transparency-Register-Review\%20_April2013.pdf (accessed 22 May 2017).

Amable, Bruno. 2017. Structural Crisis and Institutional Change in Modern Capitalism: French Capitalism in Transition. Oxford: Oxford University Press.

Arian, Asher. 2005. Politics in Israel: The Second Republic. 2nd edn. Washington, DC: CQ Press, 2005.

Aroney, Nicholas, Peter Gerangelos, Sarah Murray and James Stellios. 2015. The Constitution of the Commonwealth of Australia: History, Principle and Interpretation. Cambridge: Cambridge University Press.

Avkiran, N. K., D. K. Kanol and B. Oliver. 2016. Knowledge of Campaign Finance Regulation Reduces Perceptions of Corruption. Accounting \& Finance, 56:4, pp. 961-84.

Avital, T. 2010. The Servants of Two Masters (in Hebrew). Calcalist. Available at: http://m.calcalist.co.il/Ext/Comp/ArticleLayout/CdaArticlePrintPreview1,2506, L-3400339,00.html.

Baggott, R. 1995. Pressure Groups Today. Manchester: Manchester University Press.

Baggott, R. 2015. Understanding Health Policy. Bristol: Policy Press.

Banisar, David. 2006. Freedom of Information around the World 2006: A Global Survey of Access to Government Information Laws. London: Privacy International. 
Barari, Hassan A. 2004. Israeli Politics and the Middle East Peace Process, 1988-2002. London: Routledge.

Barrington, R. 2014. Comment: The Lobbying Bill is Either Cock-up or Conspiracy. Politics.co.uk. Available at: www.politics.co.uk/comment-analysis/2013/08/21/ comment-the-lobbying-bill-is-either-cock-up-or-conspiracy (accessed 9 January 2017).

Basil, Michael D. 1996. Standpoint: The Use of Student Samples in Communication Research. Journal of Broadcasting \& Electronic Media, 40:3, pp. 431-40.

Bauer, Elizabeth, Piotr Pielucha and Marie Thiel. 2016. Lobbying Regulation Framework in Poland. Brussels: European Parliamentary Research Service.

Baumgartner, F. R. 1996. Public Interest Groups in France and the United States. Governance, 9:1, pp. 1-22.

Baumgartner, Frank R., and Beth L. Leech. 1998. Basic Interests: The Importance of Groups on Politics and in Political Science. Princeton, NJ: Princeton University Press.

Baumgartner, Frank R., and Beth L. Leech. 2001. Interest Niches and Policy Bandwagons: Patterns of Interest Group Involvement in National Politics. The Journal of Politics, 63:4, pp. 1191-212.

Baumgartner, Frank R, Jeffrey M. Berry, Marie Hojnacki, David C. Kimball, and Beth L. Leech. 2009. Lobbying and Policy Change: Who Wins, Who Loses, and Why. Chicago: University of Chicago Press.

Bentham, Jeremy. 1999. Political Tactics: The Collected Works of Jeremy Bentham. Edited by Michael James, Cyprian Blamires and Catherine Pease-Watkin. Oxford: Oxford University Press.

Bentley, Arthur F. 1908. The Process of Government. Chicago: University of Chicago Press.

Bergsten, C. F. 1996. Globalizing Free Trade. Foreign Affairs, 75:3, pp. 105-20.

Bernhagen, P. 2013. When do Politicians Listen to Lobbyists (and Who Benefits When They do)? European Journal of Political Research, 52:1, pp. 20-43.

Bertók, János. 2008. Lobbyists, Governments and Public Trust: Building a Legislative Framework for Enhancing Transparency and Accountability in Lobbying. Paris: OECD. Available at: www.oecd.org/dataoecd/5/41/41074615.pdf.

Bjørkelo, B., W. Ryberg, S. B. Matthiesen and S. Einarsen. 2008. When you Talk and Talk and Nobody Listens: a Mixed Method Case Study of Whistleblowing and its Consequences. International Journal of Organisational Behaviour, 13:2, pp. $18-40$.

Blondel, Jean. 1995. Comparative Government: An Introduction. 2nd edn. New York: Harvester Wheatsheaf.

Boräng, F., R. Eising, H. Klüver, C. Mahoney, D. Naurin, D. Rasch and P. Rozbicka. 2014. Identifying Frames: A Comparison of Research Methods. Interest Groups and Advocacy, 3:2, pp. 188-201.

Bouwen, P. 2002. Corporate Lobbying in the European Union: The Logic of Access. Journal of European Public Policy, 9:3, pp. 365-90.

Bouwen, P. 2003. A Theoretical and Empirical Study of Corporate Lobbying in the European Parliament, European Integration Online Papers (EIoP) 7:11.

Brendon, Piers. 2008. The Decline and Fall of the British Empire 1781-1997. London: Vintage Books. 
Brinig, Margaret F., Randall G. Holcombe and Linda Schwartzstein. 1993. The Regulation of Lobbyists. Public Choice, 77:2, pp. 377-84.

Broz, J. L. 2002. Political System Transparency and Monetary Commitment Regimes. International Organisation, 56:4, pp. 861-87.

Burson-Marsteller. 2005. The Definitive Guide to Lobbying in European in European Institutions - Based on a Survey of the EP, the Council and the Commission. Brussels: Burson-Marsteller.

Byrne, Elaine. 2012. Political Corruption in Ireland 1922-2010: A Crooked Harp? Manchester: Manchester University Press.

Cabinet Office. 2015. Ministerial Code. London: British Government.

Campos, Nauro F. and Francesco Giovannoni. 2006. Lobbying, Corruption and Political Influence. Centre for Economic Policy Research, No. 5886, pp. 1-31.

Cave, T., and A. Rowell. 2015. A Quiet Word: Lobbying, Crony Capitalism and Broken Politics in Britain. London: Vintage Books.

Chalmers, A. W. 2011. Interests, Influence and Information: Comparing the Influence of Interest Groups in The European Union. Journal of European Integration, 33:4, pp. 471-86.

Chambers, S. 2003. Deliberative Democratic Theory. Annual Review of Political Science, 6:1, pp. 307-26.

Chari, Raj. 1998. Spanish Socialists, Privatising the Right Way? West European Politics, 21:4, pp. 163-79.

Chari, Raj. 2008. Why Did the Irish Reject Lisbon? An Analysis of Referendum Results. Analysis of the Real Instituto Elcano, Madrid: ARI.

Chari, Raj. 2015. Life After Privatization. Oxford: Oxford University Press.

Chari, Raj. 2016. Open Government Partnership Independent Reporting Mechanism: Ireland Progress Report 2014-15. Available at: www.opengovpartnership.org/ sites/default/files/Ireland_2014-15_Final.pdf.

Chari, Raj, and P. Bernhagen, 2011. Financial and Economic Crisis: Explaining the Sunset Over the Celtic Tiger. Irish Political Studies, 26:4, pp. 473-88.

Chari, Raj, and Francesco Cavatorta. 2002. Economic Actors' Political Activity on 'Overlap Issues': Privatisation and EU State Aid Control. West European Politics, 25:4, pp. 119-42.

Chari, Raj, and S. Kritzinger. 2006. Understanding EU Policy Making. London/Ann Arbour: Pluto/University of Michigan Press.

Chari, Raj, and D. H. O’Donovan. 2011. Lobbying the European Commission: Open or Secret? Socialism and Democracy, 25:2 (July), pp. 104-24.

Chari, Raj, J. Hogan and G. Murphy. 2010. Regulating Lobbying: A Global Comparison. Manchester: Manchester University Press.

Chari, Raj, G. Murphy and J. Hogan. 2007. Regulating Lobbyists: A Comparative Analysis of the United States, Canada, Germany and the European Union. The Political Quarterly, 78:3, pp. 422-38.

Childs, David. 2002. Britain Since 1939: Progress and Decline. 2nd edn. Basingstoke: Hampshire.

Christiansen, Thomas, and Simona Piattoni. 2004. Informal Governance in the EU. London: Edward Elgar.

Christensen, T., and P. Lægreid. 2007. Regulatory Agencies - The Challenges of Balancing Agency Autonomy and Political Control. Governance, 20:3, pp. 499-520. 
Cienski, Jan. 2015. Poland's Constitutional Crisis Goes International. Politico. 24 December. Available at: www.politico.eu/article/poland-constitution-crisiskaczynski-duda.

Citizen Conference on State Legislatures. 1971. State Legislatures: An Evaluation of Their Effectiveness. New York: Praeger.

COEC (Chief Official Ethics Commission of the Republic of Lithuania). 2007. Presentation to the OECD symposium 'Lobbying: Enhancing Transparency and Accountability', June.

Coen, D. 1997. The Evolution of the Large Firm as a Political Actor in the European Union. Journal of European Public Policy, 4:1, pp. 91-108.

Coen, D. 1998. The European Business Interest and the Nation State: Large Firm Lobbying in the European Union and Member States. Journal of Public Policy, 18:1, pp. $75-100$.

Coen, D. 2007. Empirical and Theoretical Studies in EU Lobbying. Journal of European Public Policy, 14:3, pp. 333-45.

Coen, D., and A. Katsaitis. 2013. Chameleon Pluralism in the EU: An Empirical Study of the European Commission Interest Group Density and Diversity across Policy Domains. Journal of European Public Policy, 20:8, pp. 1104-19.

Collier, D. 1997. Comparative Method in the 1990s. APSA-CP: Newsletter of the APSA Organized Section in Comparative Politics, 9:1, pp. 1-5.

Collins, Neil, and Aodh Quinlivan. 2010. Multi-level Governance, in John Coakley and Michael Gallagher (eds). Politics in the Republic of Ireland, 5th edn. Abingdon: Routledge, pp. 359-80.

Corporate European Observatory (CEO). 2005. Brussels: the EU quarter. 3rd edn. (Amsterdam: CEO).

Council of Europe. 2017. Recommendation of the Committee of Ministers to member States on the legal regulation of lobbying activities in the context of public decision making (adopted by the Committee of Ministers on 22 March 2017 at the 1282nd meeting of the Ministers' Deputies). Available at: https:// search.coe.int/cm/Pages/result_details.aspx?ObjectId=0900001680700a40.

Courty, G. 2004. Radiographie du lobbying en France. Dirigier en collectivité territoriale, 7, 53-7.

Cowles, Maria Green. 1996. The EU Committee of AmCham: the Powerful Voice of American Firms in Brussels. Journal of European Public Policy, 3:3, pp. 339-58.

Coxall, Robert. 2014. Pressure Groups in British Politics. London: Routledge.

Crepaz, M. 2016. Investigating the Robustness of Lobbying Laws: Evidence from the Austrian Case. Interest Groups \& Advocacy, 5:1, pp. 5-24.

Crepaz, M. 2017. Why Do We Have Lobbying Rules? Investigating the Introduction of Lobbying Laws in EU and OECD Member States. Interest Groups and Advocacy, 6:3, pp. 231-51.

Crepaz, M., and R. Chari. 2014. The EU's Initiatives to Regulate Lobbyists: Good or Bad Administration? Cuadernos Europeos de Deusto, 51:1, pp. 71-97.

Crepaz, M., and R. Chari. 2017. Assessing the validity and reliability of measurements when evaluating public policy. Journal of Public Policy, 1-30. doi: 10.1017/S0143814X16000271.

Crepaz, M., and M. Hanegraaff. 2018. Exploring Direct Subsidies to Interest Groups in the EU. Paper presented at ECPR (Oslo) 2017. 
Crespy, A. 2014. Deliberative Democracy and the Legitimacy of the European Union: A Reappraisal of Conflict. Political Studies, 62:1, pp. 81-98.

Crowther, D., and N. Capaldi. 2008. The Ashgate Research Companion to Corporate Social Responsibility. Aldershot: Ashgate.

Curtin, D. 2006. Framing Public Deliberation and Democratic Legitimacy in the European Union, in S. Besson and J. Luis Marti (eds). Deliberative Democracy and its Discontents. Aldershot: Ashgate, pp. 133-58.

Dabertrand, Fanny. 1999. Les Institutions Communautaires face au lobbying: une comparaison entre l'attitude de la Commission et du Parlement Europeen. Memoire de fin d'etudes, Institut D'Etudes Europeennes, Universite Libre de Bruxelles.

Dahl, Robert. 1961. Who Governs? Democracy and Power in an American City. New Haven, Conn: Yale University Press.

Davies, Norman. 2005. God's Playground: A History of Poland in Two Volumes, Oxford: Oxford University Press.

Davis, Uri. 2003. Apartheid Israel: Possibilities for the Struggle Within. London: Zed Books.

De Fouloy, C. 2015. Lobbing Landscape in Lithuania. Association of Accredited Public Policy Advocates to the European Union. Brussels, www.aalep.eu/ lobbying-landscape-lithuania.

De Tocqueville, A. 2003. Democracy in America (Vol. 10). Regnery Publishing.

Dekker, R., S. Bekker, J. Cremers, I. Guardiancich and O. Molina. 2017. The Dutch Polder Model: Resilience in Times of Crisis, in Talking Through the Crisis: Social Dialogue and Industrial Relations Trends in Selected EU Countries. Geneva: International Labour Office.

Dinan, W. D., and Miller. 2012. Sledgehammers, Nuts and Rotten Apples: Reassessing the Case for Lobbying Self-Regulation in The United Kingdom. Interest Groups \& Advocacy, 1:1, pp. 105-14.

Dinan, William. 2006. Learning Lessons? The Registration of Lobbyists at the Scottish Parliament. Journal of Communication Management, 10:1, pp. 55-66.

Docherty, James C. 2010. The A to Z of Australia. Plymouth: The Scarecrow Press.

Dolowitz, D. P., and D. Marsh. 2000. Learning from Abroad: The Role Of Policy Transfer In Contemporary Policy-Making. Governance, 13:1, pp. 5-23.

Dos Santos, L. A., and P. M. Teixeira da Costa. 2014. The Contribution of Lobbying Regulation Initiatives in Addressing Political Corruption in Latin America. Journal of Public Policy, 14:3, pp. 379-91.

Drezon-Tepler, Marcia. 1990. Interest Groups and Political Change in Israel. Albany, NY: State University of New York Press.

Dror, Yehezkel. 2002. Foreword, in Moshe Maor (ed.), Developments in Israeli Public Administration. New York: Routledge, pp. vii-x.

Dryzek, John. 2000. Democracy and Beyond. Oxford: Oxford University Press.

Dudzinska, A. 2008. Non-party Lists in Local Election in Poland, in M. Reiser and E. Hoffman (eds). Farewell to the Party Model? Independent Local Lists in East and West European Countries. Wiesbaden: Springer VS, pp. 105-25.

Dunleavy, P., H. Margetts, S. Bastow and J. Tinkler. 2006. New Public Management is Dead - Long Live Digital-era Governance. Journal of Public Administration Research and Theory, 16:3, pp. 467-94. 
Dyck, Rand. 2004. Canadian Politics, Critical Approaches. 4th edn. Toronto: Thomson Nelson.

Easton, D. 1957. An Approach to the Study of Political Systems. World Politics, 9:5, pp. 383-400.

Economist. 2003. Lithuania: Baltic Tiger. Economist, 17 July.

Eising, R. 2004. Multilevel Governance and Business Interests in the European Union. Governance, 17:2, pp. 211-45.

Eising, R. 2007. Institutional Context, Organizational Resources and Strategic Choices Explaining Interest Group Access in the European Union. European Union Politics, 8:3, pp. 329-62.

Elgie, Robert. 1999. Semi-Presidentialism in Europe. Oxford: Oxford University Press.

Elgie, Robert, and Peter Fitzgerald. 2005. The President and the Taoiseach, in John Coakley and Michael Gallagher (eds). Politics in the Republic of Ireland. 4th edn. Abingdon: Routledge, pp. 305-27.

Elster, Jon. 1998. Deliberative Democracy. Cambridge: Cambridge University Press. Esping-Anderson, Gosta. 1990. Three Worlds of Welfare Capitalism. Cambridge: Polity Press.

European Commission. 1992. Communication from the Commission: An Open and Structured Dialogue with Special Interest Groups (December).

European Commission. 2001a. European Governance: A White Paper, COM (2001), 428 Final, Brussels.

European Commission. 2001b. White Paper on Governance. Official Journal, C 287, Brussels.

European Commission. 2001c. Mandelkern Report on Better Regulation. Retrieved from http://Ec.Europa.Eu/Smart-Regulation/Better_Regulation/Documents/Man delkern_Report.Pdf (accessed 20 September 2016).

European Commission. 2006. Green Paper European Transparency Initiative.

European Commission. 2011. Inter-institutional Agreement on the Transparency Register. Agreement between the European Parliament and the European Commission on the establishment of a transparency register for organisations and selfemployed individuals engaged in EU policy-making and policy implementation. Downloadable from http://eur-lex.europa.eu/legal-content/EN/TXT/PDF/?uri=C ELEX:32011Q0722(01)\&from=EN (accessed 31 May 2017).

European Commission. 2014a. Inter-institutional Agreement on the Transparency Register. European Parliament decision of 15 April 2014 on the modification of the inter-institutional agreement on the Transparency Register (2014/2010(ACI)). Available at: www.europarl.europa.eu/sides/getDoc.do?pubRef=-//EP//NONSG ML+TA+P7-TA-2014-0376+0+DOC+PDF+V0//EN (accessed 31 May 2017).

European Commission. 2014b. Opening the Windows: Commission Commits to Enhanced Transparency. Press release, Brussels, 25 November 2014. Available at: http://europa.eu/rapid/press-release_IP-14-2131_en.htm?locale=FR (accessed 1 January 2017).

European Commission. 2015. Commission and Parliament Implement New Rules on Transparency Register. Press release, Brussels, 27 January 2015. Available at: http://europa.eu/rapid/press-release_IP-15-3740_en.htm (accessed 1 January 2017). 
European Commission. 2016. Inter-institutional Agreement, proposal on a mandatory Transparency Register. Brussels, 28.9.2016 COM(2016) 627 final. Available at: https://ec.europa.eu/transparency/regdoc/rep/1/2016/EN/1-2016627-EN-F1-1.PDF (accessed 31 May 2017).

European Commission. 2017. HR: KEY FIGURE and Staff Members. Available at: http://ec.europa.eu/civil_service/docs/hr_key_figures_en.pdf (accessed 1 November 2017).

European Parliament, DG for Research. 2003. Lobbying in the European Union: Current Rules and Practices. Luxembourg: European Parliament.

European Parliament (EP). 2008. Report on the Development of the Framework for the Activities of Interest Representatives (Lobbyists) in the European Institutions. Brussels, 2.4.2008 (2007/2115(INI)). Available at: http://eur-lex.europa.eu/ legal-content/EN/TXT/PDF/?uri=CELEX:52008IP0197\&from=EN (accessed 22 May 2017).

Evans, Matt. 2007. An Institutional Framework for Policymaking: Planning and Population dispersal in Israel. Plymouth: Lexington Books.

Falk, A., S. Meier and C. Zehnder. 2013. Do Lab Experiments Misrepresent Social Preferences? The Case of Self-selected Student Samples. Journal of the European Economic Association, 11:4, pp. 839-52.

Falkner, G. 2003. EU Social Policy in the 1990s: Towards a Corporatist Policy Community. Abington: Routledge.

Feena, Alan. 2014. The Australian System of Government, in Alan Feena, Jane Robbins and John Summers (eds). Government and Politics in Australia. Frenschs Forest, NSW: Pearson Australia, pp. 12-33.

Feeney, S., J. Hogan and B. K. O'Rourke. 2017. Elite Formation in the Higher Education Systems of Ireland and the UK: Measuring, Comparing and Decomposing Longitudinal Patterns of Cabinet Members. British Educational Research Journal, 43:4, pp. 720-42.

Finkelstein, Neal D. 2000. Introduction: Transparency in Public Policy, in Neal D. Finkelstein (ed.). Transparency in Public Policy. Basingstoke: Macmillan Press Ltd.

Fink-Hafner, D. 1998. Organized Interests in the Policy-making Process in Slovenia. Journal of European Public Policy, 5:2, pp. 285-302.

Fink-Hafner, D. 2017. Slovenia, in A. Bitonti and P. Harris (eds). Lobbying in Europe. London: Palgrave Macmillan, pp. 299-311.

Fink-Hafner, D., and A. Krašovec. 2006. Europeanisation of the Slovenian Party System - From Marginal European Impacts to the Domestification of EU Policy Issues? Politics in Central Europe, 2:1, pp. 7-23.

Fisher, Roger, William Ury and Bruce Patton. 1999. Getting to Yes. Negotiating an Agreement Without Giving In. 2nd edn. London: Random House.

Forman, F. N. 1991. Mastering British Politics. 2nd edn. London: Macmillan Education Ltd.

Francis, J. C. 1993. The Politics of Regulation: A Comparative Perspective. London: Blackwell.

Galkowski, Juliusz. 2008. Poland's Experience of Developing and Implementing the Act on Legislative and Regulatory Lobbying, in Lobbyists, Government and Public Trust. Paris: OECD, pp. 127-58. 
Gallagher, M. 2017. Election indices dataset at: www.tcd.ie/Political_Science/staff/ michael_gallagher/ElSystems/index.php (accessed 13 July 2017).

Gallagher, Michael. 2005. Ireland: The Discreet Charm of PR - STV, in Michael Gallagher and Paul Mitchell (eds). The Politics of Electoral Systems. Oxford: Oxford University Press, pp. 511-32.

Gallagher, Michael, Michael Laver and Peter Mair. 2011. Representative Government in Modern Europe. New York: McGraw-Hill.

Garin González, R. 2016. El lobby feroz y la sociedad de las influencias. Santiago de Chile: Editorial Catalonia.

Garziano, Luigi. 2001. Lobbying, Pluralism and Democracy. London: Palgrave.

Gay, O., L. Maer and P. Bowers. 2012. Lobbying. Commons Briefing Papers, 1-24.

Geraats, P. M. 2002. Central Bank Transparency. The Economics Journal, 112:483, pp. 532-65.

Gilardi, F. 2005. The Institutional Foundations of Regulatory Capitalism: the Diffusion of Independent Regulatory Agencies in Western Europe. The Annals of the American Academy of Political and Social Science, 598:1, pp. 84-101.

Giorno, Guy. 2006a. Canadian Lobbyist Registration Law: Overview and Comparison. Toronto: unpublished manuscript.

Giorno, Guy. 2006b. Staying on the Right Side of the Law. Paper presented at 3rd Annual Government Relations Summit, Ottawa, Ontario, February.

Giorno, Guy. 2013. Historic First Conviction under Lobbying Act (Canada). Lobbying Law Bulletin Fasken Martineau. Available at: www.fasken.com/en/ historic-first-charge-laid-under-lobbying-act-canada-05-01-2013.

Giorno, Guy. 2016a. Attendance at Political Fundraising Events is subject to Lobbying and Ethics Laws. Lobbying Law Bulletin Fasken Martineau, available at: www.fasken.com/en/attendance-at-political-fundraising-events-is-subject-tolobbying-and-ethics-laws.

Giorno, Guy. 2016b. Expanded Ontario Lobbying Law Will Take Effect July 1st. Lobbying Law Bulletin Fasken Martineau. Available at: www.fasken.com/en/ expanded-ontario-lobbying-law-will-take-effect-july-1st.

Giorno, Guy. 2016c. PEI Government Introduces Long-Awaited Lobbying Law Strong Enforcement, But Many Gaps. Lobbying Law Bulletin Fasken Martineau. Available at: www.fasken.com/en/pei-government-introduces-long-awaited-lobby ing-law-strong-enforcement-but-many-gaps.

Giorno, Guy, and Kyle Morrow. 2015. Brampton will be Fourth Canadian City to Implement Comprehensive Lobbyist Registration Law. Lobbying Law Bulletin Fasken Martineau, 25 November. Available at: www.fasken.com/en/bramptonwill-be-fourth-canadian-city-to-implement-comprehensive-lobbyist-registrationlaw.

Glowik, Mario, and Slawomir Smyczek. 2011. International Marketing Management: Strategies, Concepts and Cases in Europe. Munich: Oldenbourg Verlag Munchen.

Goldstein, Stephen M. 2015. China and Taiwan. Cambridge: Polity Press.

Gordon, Neil. 2005. State Lobbyists Near the \$1 Billion Mark. Laws in Flux for 19 States. Center for Public Integrity. www.publicintegrity.org/2005/08/10/5905/ state-lobbyists-near-1-billion-mark.

Government of Canada, 2008. The Lobbying Act - A Summary of New Requirements. Ottawa: Office of the Registrar of Lobbyists. 
Government of the UK. 2014. Transparency of Lobbying, Non-Party Campaigning and Trade Union Administration Act 2014. London: The Stationery Office. Available at: www.legislation.gov.uk/ukpga/2014/4/pdfs/ukpga_20140004_en. pdf (accessed 15 October 2017).

Gray, Kevin. 2015. Labour and Development in East Asia: Social Forces and Passive Revolution. Abingdon: Routledge.

Gray, Virginia, and David Lowery. 1998. State Lobbying Regulations and Their Enforcement: Implications for the Diversity of Interest Communities. State and Local Government Review, 30:2, pp. 78-91.

Greenwood, Justin. 1998. Regulating Lobbying in the European Union. Parliamentary Affairs, 51:4, pp. 587-99.

Greenwood, Justin. 2007. Interest Representation in the European Union. 2nd edn. Basingstoke: Palgrave.

Greenwood, J. 2011. Interest Representation in the European Union. 3rd edn. London: Palgrave Macmillan.

Greenwood, J., and J. Dreger. 2013. The Transparency Register: A European Vanguard of Strong Lobby Regulation? Interest Groups \& Advocacy, 2:2, pp. 139-62.

Greenwood, J., and C. S. Thomas. 1998. Introduction: Regulating Lobbying in the Western World. Parliamentary Affairs, 51:4, pp. 487-99.

Griffith, Gareth. 2008. The Regulation of Lobbying, Briefing Paper No. 5/08, Sydney: NSW Parliamentary Library Research Service. Available at: www.parliament.nsw.gov.au/prod/parlment/publications.nsf/key/TheRegulationofLobbying.

Grimmelikhuijsen, S. G. 2010. Transparency of Public Decision-Making: Towards Trust in Local Government? Policy \& Internet, 2:1, pp. 5-35.

Groll, T., and C. J. Ellis. 2014. A Simple Model of the Commercial Lobbying Industry. European Economic Review, 70, pp. 299-316.

Groseclose, Tim, and Nolan McCarty. 2001. The Politics of Blame: Bargaining Before an Audience. American Journal of Political Science, 45:1, pp. 100-20.

Grossman, E., and S. Saurugger. 2004. Challenging French Interest Groups: The State, Europe and the International Political System. French Politics, 2:2, pp. 203-20.

Gust, Liepa. 2012. A New Civics in the Digital Age: Connecting Online and Offline Activism in Lithuania. Unpublished thesis: Clemson University.

Gutmann, Amy, and Dennis Thompson. 1996. Democracy and Disagreement. Cambridge, MA: The Belknap Press of Harvard University Press.

Gutmann, Amy, and Dennis Thompson. 2004. Why Deliberative Democracy? Princeton NJ: Princeton University Press.

Hall, P., and J. Keeler. 2001. Interest Representation and the Politics of Protest. Developments in French Politics, 2, pp. 50-67.

Hamilton, N. 2012. Mexico. In H. Vanden and G. Prevost, Politics of Latin America: The Power Game. 3rd edn. Oxford: Oxford University Press, pp. 300-37.

Hamm, K., A. Weber and B. Anderson. 1994. The Impact of Lobbying Laws and Their Enforcement: A Contrasting View. Social Sciences Quarterly, 75:2, pp. 378-81.

Hanegraaff, M., A. Poletti and J. Beyers. 2016. Explaining Varying Lobbying Styles Across the Atlantic: An Empirical Test of the Cultural and Institutional Explanations. Journal of Public Policy, 37:4, pp. 459-86. 
Harkov, Lahav. 2014. The lobbying dilemma. The Jerusalem Post, 23 April. Available at: www.jpost.com/National-News/The-lobbying-dilemma-350138.

Harpaz, Itzhak. 2007. The State of Trade Unionism in Israel. In Craig Phelan (ed.). Trade Union Revitalisation: Trends and Prospects in 34 Countries. New York: Peter Land.

Harrison, R. J. 1980. Pluralism and corporatism: the political evolution of modern democracies. Allen \& Unwin.

Harvard Law Review. 2002. The Political Activity of Think Tanks: The Case for Mandatory Contributor Disclosure. Harvard Law Review, 11:5, pp. 1502-24.

Haute Autorité Pour la Transparence de la Vie Publique. 2016. Rapport D'activité (2016). Available at: www.hatvp.fr/wordpress/wp-content/uploads/2017/04/ RA2016.pdf (accessed 23 October 2017).

Hayes, Billy. 2014. The Gagging Bill Looks Designed to Undermine Trade Unions. Guardian, 28 January. Available at: www.theguardian.com/commentisfree/2014/ jan/29/lobbying-bill-trade-unions-law.

He, Kai, and Huyiun Feng. 2013. Prospect Theory and Foreign Policy Analysis in the Asia Pacific: Regional Leaders and Risky Behavior. New York, NY: Routledge.

Héritier, Adrienne. 1999. Elements of Democratic Legitimation in Europe: An Alternative Perspective. Journal of European Public Policy, 6:2, pp. 269-82.

Hermann, A. T., M. Pregernig, K. Hogl and A. Bauer. 2015. Cultural Imprints on Scientific Policy Advice: Climate Science-Policy Interactions within Austrian Neo-corporatism. Environmental Policy and Governance, 25:5, pp. 343-55.

Heumann, M., A. Friedes, L. Cassak, W. Wright and E. Joshi. 2013. The World of Whistleblowing: From the Altruist to the Avenger. Public Integrity, 16:1, pp. 25-52.

Hine, D., and G. Peele. 2016. The Regulation of Standards in British Public Life: Doing the Right Thing. Manchester: Manchester University Press.

Hix, Simon. 2002. Constitutional Agenda Setting Through Discretion in Rule Interpretations: Why the European Parliament Won at Amsterdam. British Journal of Political Science, 32:2, pp. 259-80.

Hix, Simon. 2005. The Political System of the European Union. 2nd edn. London: Palgrave.

Hix, S., A. G. Noury and G. Roland. 2007. Democratic Politics in the European Parliament. Cambridge: Cambridge University Press.

Hix, S., and B. Høyland. 2011. The Political System of the European Union. London: Palgrave Macmillan.

Hogan, John, Raj Chari and Gary Murphy. 2011. Regulating Australia's Lobbyists: Coming Full Circle to Promote Democracy? Journal of Public Affairs, 11:1, pp. 35-48.

Hogan, John, Raj Chari and Gary Murphy. 2012. Walking on Sunshine or Away from It. Available at: http://arrow.dit.ie/cgi/viewcontent.cgi? article=1059\&conte $\mathrm{xt}=$ aaschsslarts.

Hogan, John, Gary Murphy and Raj Chari. 2008. Next Door They Have Regulation but not here ...: Assessing the Opinions of Actors in the Opaque World of Unregulated Lobbying. Canadian Political Science Review, 2:3, pp. 125-51.

Hogenboom, B. 2014. The Changing Politics of Lobbying: Private Sector Organizations in Mexico. Journal of Public Affairs, 14:3-4, pp. 296-309. 
Holman, Craig. 2008. Lobbying Reform in the United States and the European Union: Progress on Two Continents. Paper presented at the Conference of the American Political Science Association, Boston, MA, 31 August.

Holman, Craig. 2009. Lobbying Reform in the United States and the European Union: Progress on Two Continents, in Conor McGrath (ed.). Interest Groups and Lobbying: Volume One - The United States, and Comparative Studies. Lewiston: Edwin Mellen Press, pp. 267-96.

Holman, C., and W. Luneburg. 2012. Lobbying and Transparency: A Comparative Analysis of Regulatory Reform. Interest Groups \& Advocacy, 1:1, pp. 75-104.

Horner, Jack. 2004. Racial Justice: Seeking Racial Justice: An Insider's Memoir of the Movement for Aboriginal Advancement, 1938-1978. Canberra: Aboriginal Studies Press.

House of Commons. 2013. House of Commons Hansard, Second Reading, 3 September 2013.

Howlett, Michael, and M. Ramesh. 2003. Studying Public Policy: Policy Cycles and Policy Subsystems. Oxford: Oxford University Press.

Hrebenar, Ronald J. 1997. Interest Group Politics in America. 3rd edn. New York: M.E. Sharpe.

Hrebenar, Ronald J., Courtney H. McBeth and Bryson B. Morgan. 2008. Interests and Lobbying in Lithuania: A Spectrum of Development. Journal of Public Affairs, 8, pp. 51-65.

Hrebenar, Ronald J., and Bryson B. Morgan. 2011. Worldwide Perspective on Lobbying. In Amy Handlin (ed.). Dirty Deals? An Encyclopedia of Lobbying, Political Influence, and Corruption. Santa Barbara, CA: ABC-CIO, pp. 89-112.

Hrebenar, Ronald J., and Bryson B. Morgan. 2009. Lobbying in America: A Reference Book. Santa Barbara, CA: ABC-CLIO.

Hrebenar, Ronald J., Akira Nakainura and Akio Nakamura. 1998. Lobbying Regulation in the Japanese Diet. Parliamentary Affairs, 51:4, pp. 551-58.

Hunter, Kennith G., Laura Ann Wilson and Gregory G. Brunk. 1991. Societal Complexity and Interest-Group Lobbying in the American States. The Journal of Politics, 53:2, pp. 488-503.

Integrity and Prevention of Corruption Act. 2010. Available at: www.kpk-rs.si/ upload/datoteke/ZintPK-ENG.pdf.

Iyengar, Rishi. 2016. Taiwan's Democratic Progressive Party Takes Control of Parliament. Time, 1 February. Available at: http://time.com/4202005/ taiwan-democratic-progressive-party-dpp-parliament.

Jahn, D. 2014. Changing of the Guard: Trends in Corporatist Arrangements in 42 Highly Industrialized Societies from 1960 to 2010. Socio-Economic Review, 14:1, pp. 47-71.

Jann, W., and K. Wegrich. 2007. Theories of the Policy Cycle. In F. Fischer, G. J. Miller and M. S. Sidney (eds). Handbook of Public Policy Analysis: Theory, Politics and Method. New York: CRC Press, Taylor \& Francis, pp. 43-63.

Jasiecki, Krzysztof. 2006. Regulating Lobbying in Poland: Background, Scope and Expectations, Council of Europe. Available at: www.coe.int/T/DG1/ LegalCooperation/Economiccrime/cybercrime/cy \% 20 activity \% 20 Interface2006/143\%20_2006_-if-rep\%20jasie.pdf. 
Jegelevičius, Linas. 2015. Lithuanian NGOs Grapple with State's Mistrust and Shady Image. The Baltic Times. Available at: www.baltictimes.com/lithuanian_ ngos_grapple_with_state__s_mistrust_and_shady_image.

Johnson, C. 1982. MJTI and the Japanese Miracle: The Growth of Industrial Policy, 1925-1975. Stanford: Stanford University Press.

Joint Transparency Register Secretariat. 2015. Annual Report on the Operations of the Transparency Register. Presented by the Secretaries-General of the European Parliament and the European Commission to Ms Sylvie Guillaume, Vice-President of the European Parliament and Mr Frans Timmermans, First Vice-President of the European Commission. Available at: http://ec.europa.eu/transparencyregister/ public/staticPage/displayStaticPage.do?locale=en \& reference=ANNUAL_ REPORT (accessed 31 May 2017).

Jordan, Grant. 1991. The Commercial Lobbyists. Aberdeen: Aberdeen University Press.

Jordan, Grant. 1998. Towards Regulation in the UK: From 'General Good Sense' to 'Formalised Rules'. Parliamentary Affairs, 51:4, pp. 524-37.

Jordan, G., and W. Maloney. 2007. Democracy and Interest Groups: Enhancing Participation? London: Palgrave Macmillan.

Kallas, S. 2005. Transparency Restores Confidence in Europe. Speech of Vice President of the European Commission, Siim Kallas, to the European Policy Institutes Network, at the Centre of European Policy Studies. Brussels, 20 October 2005. Available at: http://europa.eu/rapid/press-release_SPEECH-05-628_en.htm (accessed 31 May 2017).

Kallas, S. 2007. Letter to Siim Kallas from the Committee on Constitutional Affairs. September 12, 2007. Available at: http://ec.europa.eu/archives/commission_20042009/ kallas/work/eu_transparency/lobbying_en.htm (accessed 22 May 2017).

Kalniņš, Valts. 2005. Parliamentary Lobbying, Between Civil Rights and Corruption. Rīga: Nordik Publishing House.

Kalniņš, Valts 2011. Transparency in Lobbying: Comparative Review of Existing and Emerging Regulatory Regimes. Prague: Policy Association for an Open Society. Available at: http://pasos.org/wp-content/uploads/2011/10/Comparativereport_lobbying-PASOS.doc.

Kan, Shirley A. 2014. China/Taiwan: Evolution of the 'One China' Policy - Key Statements from Washington, Beijing, and Taipei. Congressional Research Service. Available at: www.fas.org/sgp/crs/row/RL30341.pdf.

Kanol, D. 2012. Should The European Commission Enact A Mandatory Lobby Register? Journal of Contemporary European Research, 8:4, pp. 520-29.

Kanol, D. 2018. Knowledge of Lobbying Regulations and Attitudes Toward Politics: Findings from a Survey Experiment in Cyprus. Public Integrity, 20:2, pp. 163-78.

Keane, Bernard. 2008. Why Faulkner's Lobbyist Register Won't Work. Crikey, 3 April. Available at: www.crikey.com.au/2008/04/03/why-faulkners-lobbyistregister-wontwork.

Keeling, S., S. Feeney and J. Hogan. 2017. Transparency! Transparency?: Comparing the New Lobbying Legislation in Ireland and the UK. Interest Groups \& Advocacy, 6:2, pp. 121-42.

Keohane, Robert O., and Joseph Nye. 2002. Redefining Accountability for Global Governance. In M. Kahler and D. Lake (eds). Governance in a Global Economy: Political Authority in Transition. Princeton: Princeton University Press. 
Kernell, S., and Gary C. Jacobson. 2003. The Logic of American Politics. 2nd edn. Washington, DC: CQ Press.

Klemencic, Goran. 2006. A Review of the Compliance of the Lithuania Legal and Institutional Framework against Corruption. Vilnius: United Nations Development Programme, Lithuania Office. Available at: www.transparency.lt/new/ images/ti_lithuania_uncac.pdf.

Kohn, S. 2011. Whistleblower's Handbook: A Step-by-Step Guide to Doing What's Right and Protecting Yourself. Gilford, CA: Lyons Press.

Kolko, Gabriel. 1965. The Triumph of Conservatism: A Reinterpretation of American History, 1900-1916. Princeton, NJ: Princeton University Press.

Kollmannová, Denisa Kasl, and Anna Matušková. 2014. Public Affairs in the Czech Republic: An Exploratory Study of the Current Situation, Journal of Public Affairs, 14:1, pp. 54-66.

Köppl, P. 2017. Austria. In A. Bitonti and P. Harris (eds.). Lobbying in Europe: Public Affairs and the Lobbying Industry in 28 EU Countries, 45-58. London: Palgrave Macmillan.

Köppl, P., and J. Wippersberg. 2014. The State Of Public Affairs in Austria. Journal of Public Affairs, 14:1, pp. 31-43.

Korkut, Umar. 2005. The Relationship Between Democratization and Invigoration of Civil Society: The Case of Hungary and Poland. East European Quarterly, 39:2, pp. 149-77.

Krajewski, Andrzej. 2006. Country Report: Poland (2006). Washington, DC: Freedom House. Available at: www.refworld.org/docid/473aff39c.html.

Krajewski, Andrzej. 2008. Poland. In Nations in Transit 2008. Washington, DC: Freedom House, pp. 447-66. Available at: www.refworld.org/pdfid/4865cf5d27. pdf.

Krippendorff, K. 2004. Reliability in Content Analysis: Some Common Misconceptions and Recommendations. Human Communication Research, 30:3, pp. 411-33.

Kubicek, P. 2015. European Politics. Routledge: London.

Kwiatkowski, Bartozs, Radana Deščíková and Petr Bouda. 2016. Lobbying - a Risk or an Opportunity? Lobbying Regulation in the Polish, Slovak, and Czech Perspective. Krakow: Frank Bold. Available at: www.en.frankbold.org/sites/ default/files/publikace/analyza_lobbying__web.pdf.

Lai, Mark Wen-yi. 2012. Cross Straits Hostility and Economic Cooperation. In Baogang Guo and Chung-Chian Teng (eds). Taiwan and the Rise of China: Cross-strait Relations in the Twenty-first Century. Plymouth: Lexington Books, pp. 33-50.

Landis, R., and G. Koch. 1977. The Measurement of Observer Agreement for Categorical Data. Biometrics, 33:1, pp. 159-74.

Lane, Thomas. 2014. Lithuania: Stepping Westward. London: Routledge.

Largerlof, Johan, and Lars Frisell. 2004. Lobbying, Information Transmission and Unequal Representation. Centre for Economic Policy Research, No. 4313, pp. $1-27$.

Leach, R., B. Coxall and L. Robins. 2007. British Politics. 2nd edn. Basingstoke: Palgrave.

Lehmbruch, G. 1977. Liberal Corporatism and Party Government. Comparative Political Studies, 10:1, pp. 91-126. 
Liang, Ellis. 2016. The Kuomintang Loses Taiwan's Next Generation. The Wall Street Journal, 11 January. Available at: www.wsj.com/articles/the-kuomintangloses-taiwans-next-generation-1452535578.

Lijphart, Arend. 1999. Patterns of Democracy: Government Forms and Performance in Thirty-six Countries. New Haven, CT: Yale University Press.

Lindblom, C. E. 1969. The Science of 'Muddling Through'. Public Administration: Concepts and Cases, pp. 151-61.

Lindblom, Charles. 1977. Politics and Markets: The World's Political-economic Systems. New York: Basic Books.

Lindstedt, C., and D. Naurin. 2006. Transparency against Corruption: A CrossCountry Study. Paper presented at the IPSA 20th World Congress, Fuhuoka, Japan, 9-13 July.

Lloyd, C. 1990. Political Lobbying: Dynamiting or Gentle Persuasion? In P. Cullen (ed.). No is Not an Answer: Lobbying for Success. Sydney: Allen \& Unwin.

Lord, Christopher. 2004. A Democratic Audit of the European Union. Basingstoke: Palgrave.

Lowery, D., and V. Grey. 1997. How Some Rules Just Don't Matter: The Regulation of Lobbyists. Public Choice, 91:2, pp. 139-47.

Lu, Wilbur Bing-Yan. 2015. The Power of Influencing Policies, or Getting Their Share and More: Interest Groups in Taiwan. In Yu-Ying Kuo (ed.). Analysis in Taiwan. Bristol: Policy Press, pp. 95-110.

MacCarthaigh, Muiris. 2005. Accountability in Irish Parliamentary Politics. Dublin: Institute of Public Administration.

MacCarthaigh, Muiris, and Shane Martin. 2015. Bicameralism in the Republic of Ireland: The Seanad Abolition Referendum. Irish Political Studies, 30:1, pp. 121-31.

MacKenzie, G. C. 2002. Scandal Proof: Do Ethics Laws Make Government Ethical? Washington, DC: Brookings.

Maggetti, M., and F. Gilardi. 2016. Problems (and Solutions) in the Measurement of Policy Diffusion Mechanisms. Journal of Public Policy, 36:1, pp. 87-107.

Maguire, S. 2011. Can Data Deliver Better Government? The Political Quarterly, 82:4, pp. 522-5.

Mahler, Gregory S. 2016. Politics and Government in Israel: The Maturation of a Modern State. 3rd edn. Lanham, MA: Rowan \& Littlefield.

Mahoney Christine. 2004. The Power of Institutions: State and Interest Group Activity in the EU. European Union Politics, 5:4, pp. 441-66.

Mahoney, Christine. 2007. Lobbying Success in the US and the EU. Journal of Public Policy, 27:1, pp. 44-45.

Mahoney, C. 2008. Brussels Versus the Beltway: Advocacy in the United States and the European Union. Washington, DC: Georgetown University Press.

Mahoney, J., and G. Goertz. 2006. A Tale of Two Cultures: Contrasting Quantitative and Qualitative Research. Political Analysis, 14:3, pp. 227-49.

Makowski, Grzegorz, 2011. Regulation of Lobbying in Poland. Prague: EUROPEUM. Available at: www.researchgate.net/publication/281372519_ Regulation_of_Lobbying_in_Poland.

Malone, Mary, 2004. Regulation of Lobbyists in Developed Countries. Dublin: Institute of Public Administration. 
Marangos, John. 2002. The Political Economy of Shock Therapy. Journal of Economic Surveys, 16:1, pp. 41-76.

Marcus, Jonathan. 2009. The 2009 Israeli Election: A Bump in the Road to Peace? The Washington Quarterly, 32:3, pp. 55-69.

Marsh, Ian. 2004. Political Integration and the Outlook for the Australian Party System: Party Adaption or Regime Change? In Paul Boreham, Geoffrey Stokes and Richard Hall (eds). The Politics of Australian Society. Frenchs Forest, NSW: Pearson, pp. 119-40.

Martin Albro. 1971. Enterprise Denied: Origins of the decline of American Railroads, 1897-1917. New York: Columbia University Press.

Masso, Jaan, Kerly Espenberg, Anu Masso, Inta Mierina and Kaia Philips. 2014. Between Economic Growth and Social Justice: Different Inequality Dynamics in the Baltic States. In Brian Nolan, Wiemer Salverda, Daniele Checchi, Ive Marx, Abigail McKnight, Istvan Gyorgy Toth and Herman van de Werfhorst (eds). Changing Inequalities \& Societal Impacts in Rich Countries: Thirty Countries' Experiences. Oxford: Oxford University Press, pp. 96-125.

Mayer, Lawrence C., John H. Burnett and Suzanne Ogden. 1993. Comparative Politics: Nations and Theories in a Changing World. Englewood Cliffs, N.J.: Prentice Hall.

McCahill, M. W. 2014. Introduction. Parliamentary History, 33:1, pp. 1-61.

McCubbins, M., R. Noll and B. Weingast. 1987. Administrative Procedures as Instruments of Political Control. Journal of Law, Economic and Organisation, $3: 2$, pp. $243-77$.

McElroy, G., and K. Benoit. 2007. Party Groups and Policy Positions in the European Parliament. Party Politics, 13:1, pp. 5-28.

McElroy G., and K. Benoit. 2010. Party Policy and Group Affiliation in the European Parliament. British Journal of Political Science, 40:2, pp. 377-98.

McGrath, C. 2005. Lobbying in Washington, London, and Brussels: The Persuasive Communication of Political Issues. Vol. 26. New York: Edwin Mellen Press.

McGrath, Conor. 2008. The Development and Regulation of Lobbying in the New Member States of the European Union. Journal of Public Affairs, 8:1-2, pp. 15-32.

McGrath, Conor. 2009a. Transparency, Access and Influence: Regulating Lobbying in the UK. Toronto Meeting Paper, 1-62. Available at: http://papers.ssrn.com/ sol3/papers.cfm?abstract_id=1450819 (accessed 12 August 2016).

McGrath, Conor. 2009b. The Lobbyist with 'Balls of Iron and a Spine of Steel': why Ireland Needs Lobbying Reform. Journal of Public Affairs, 9:4, pp. 256-71.

McGrath, Conor (ed.). 2009c. Interest Groups and Lobbying in The United States, and Comparative Perspectives. Lewiston: Edwin Mellen Press.

McGrath, Conor (ed.). 2009d. Interest Groups and Lobbying in Europe. Lewiston, New York: Edwin Mellen Press.

McGrath, Conor (ed.) 2009e. Interest Groups and Lobbying in Latin America, Africa, the Middle East, and Asia. Lewiston: Edwin Mellen Press.

McGrath, Conor. 2011. Lobbying in Ireland: A Reform Agenda. Journal of Public Affairs, 11:2, pp. 127-34.

McGrath, Conor. 2016. The British Political System. In A. Bitonti and P. Harris (eds). Lobbying in Europe: Public Affairs and the Lobbying Industry in $28 \mathrm{EU}$ Countries. London: Palgrave, pp. 333-50. 
McGrath, Conor. 2017. United Kingdom. In A. Bitonti and P. Harris (eds). Lobbying in Europe: Public Affairs and the Lobbying Industry in 28 EU Countries. London: Palgrave Macmillan.

McKeown, Deirdre. 2014. Who Pays the Piper? Rules for Lobbying Governments in Australia, Canada, UK and USA. Parliamentary Library Research Paper Series 2014-15.

McLynn, F. 2000. Villa and Zapata: A Biography of the Mexican Revolution. Jonathan Cape. London.

McMenamin, I. 2004. Varieties of Capitalist Democracy: What Difference Does East-Central Europe Make? Journal of Public Policy, 24:3, pp. 259-74.

Meier, D, 2017. 'Germany'. In A. Bitonti and P. Harris (eds). Lobbying in Europe: Public Affairs and the Lobbying Industry in 28 EU Countries. London: Palgrave Macmillan, pp. 159-70.

Menadue, John. 2015. How the Rise of the Lobbyist is Corrupting Australia's Democracy. The Age, 18 May. Available at: www.theage.com.au/comment/how-the-riseof-the-lobbyist-is-corrupting-australias-democracy-20150515-gh2iyw.html.

Mengin, Francoise. 2015. Fragments of an Unfinished War: Taiwanese Entrepreneurs and the Partition of China. Oxford: Oxford University Press.

Michalowitz, Irina. 2006. The European Platform of Women Scientists and Potential, Obstacles and Dangers of Civil Society Participation in Multi-Level Governance Systems. Presented at the Institute for International Integration Studies, TCD.

Michel, H. 2013. EU Lobbying and the European Transparency Initiative: A Sociological Approach to Interest Groups. In N. Kauppi (ed.). A Political Sociology of Transnational Europe. Colchester: ECPR Press, pp. 53-78.

Mikhaylov, S., M., Laver and K. Benoit. 2012. Coder Reliability and Misclassification in the Human Coding of Party Manifestos. Political Analysis, 20:1, pp. 79-91.

Miliband, Ralph. 1969. The State in Capitalist Society. London: Weidenfeld \& Nicolson.

Moncrieffe, J. M. 1998. Reconceptualizing Political Accountability. International Political Science Review, 19:4, pp. 387-406.

Moran, Michael. 2007. The British Regulatory State: High Modernism and HyperInnovation. Oxford: Oxford University Press.

Moran, Michael. 2015. Politics and Governance in the UK. 3rd edn. London: Palgrave.

Moravscik, Andrew. 1993. Preferences and Power in the European Community: A Liberal Intergovernmentalist Approach. Journal of Common Market Studies, 31:4, pp. 473-524.

Mulcahy, Suzanne. 2015. Lobbying in Europe: Hidden Influence, Privileged Access. Brussels: Transparency International.

Müller, C. W. 1997. Das Parteiensystem Handbuch. In P. Dachs (ed.). Handbuch Des Politischen System Österreichs. Wien: Manz, pp. 215-359.

Munck, G., L., and J. Verkuilen. 2002. Conceptualizing and Measuring Democracy. Comparative Political Studies, 35:1, pp. 5-34.

Murphy, Gary. 2010a. Interest Groups in the Policy-making Process. In John Coakley and Michael Gallagher (eds). Politics in the Republic of Ireland. 5th edn. Abingdon: Routledge, pp. 327-58. 
Murphy, Gary. 2010b. Influencing Political Decision Making: Interest Groups and Elections in Independent Ireland. Irish Political Studies, 25:4, pp. 563-80.

Murphy, Gary. 2017. Ireland. In A. Bitonti and P. Harris (eds). Lobbying in Europe: Public Affairs and the Lobbying Industry in 28 EU Countries. London: Palgrave Macmillan.

Murphy, Gary, and Conor McGrath. 2011. The Curious Case of Lobbying in Ireland. Journal of Public Affairs, 11:2, pp. 71-3.

Murphy, Gary, John Hogan and Raj Chari. 2009. The Politics of Regulating Lobbyists: Assessing the Attitudes of Actors in the World of Regulated Lobbying. In Conor McGrath (ed.). Interest Groups \& Lobbying: Volume One - The United States, and Comparative Studies. Edwin Mellen Press, pp. 297-328.

Murphy, Gary, John Hogan and Raj Chari. 2011. Lobbying Regulation in Ireland: Some Thoughts from the International Evidence. Journal of Public Affairs, 11:2, pp. 111-19.

Murphy, Mary C. 2006. Reform of Dáil Éireann: The Dynamics of Parliamentary Change. Parliamentary Affairs, 59:3, pp. 437-53.

Naurin, Daniel. 2006. Transparency, Publicity, Accountability - The Missing Links. Swiss Political Science Review, 12:3, pp. 90-8.

Naurin, Daniel. 2007. Backstage Behaviour? Lobbyists in Public and Private Settings in Sweden and the European Union. Comparative Politics, 39:2, pp. 209-28.

Newmark, A. J. 2005. Measuring State Legislative Lobbying Regulation, 1990-2003. State Politics and Policy Quarterly, 5:2, pp. 182-91.

Newmark, Adam J. 2009. Personal Relationships and Information as Lobbying Strategies: Adaptation in the Context of the American States. In Conor McGrath (ed.). Interest Groups and Lobbying: Volume One - The United States, and Comparative Studies. Lewiston: Edwin Mellen Press, pp. 75-102.

Nolan Committee. 1995. Standards in Public Life, Vol. I, Cm 2850-I HMSO, London. Available at: www.archive.official-documents.co.uk/document/cm28/ 2850/2850.htm.

Nownes, Anthony J. 2006. Total Lobbying: What Lobbyists Want (and How They Try to Get It). Cambridge: Cambridge University Press.

O'Flynn, I. 2006. Deliberative Democracy and Divided Societies. Edinburgh: Edinburgh University Press.

OECD. 2008. Lobbyists, Government and Public Trust: Building a Legislative Framework for Enhancing Transparency and Accountability in Lobbying. Paris: OECD.

OECD. 2009. Lobbyists, Governments and Public Trust, Volume 1: Increasing Transparency Through Legislation. Paris: OECD.

OECD. 2012. Lobbyists, Governments and Public Trust, Volume 2: Promoting Integrity Through Self-regulation. Paris: OECD.

OECD. 2014a. Lobbyists, Government and Public Trust: Implementing the OECD Principles for Transparency and Integrity In Lobbying, Volume 3. Paris: OECD. OECD. 2014b. Mexico: The Regulation of Lobbying in the Legislative Branch. In Lobbyists, Governments, and Public Trust, Volume 3: Implementing the OECD Principles for Transparency and Integrity in Lobbying. Paris: OECD.

OECD. 2014c. Chile: Regulation of Lobbying. In Lobbyists, Governments and Public Trust, Volume 3: Implementing the OECD Principles for Transparency and Integrity in Lobbying. Paris: OECD. 
OECD. 2015. OECD Public Governance Reviews: Lithuania. Fostering Open and Inclusive Policy Making. Paris: OECD.

OECD, 2017. Mexico Economic Survey. Available at: www.oecd.org/eco/surveys/ Mexico-2017-OECD-economic-survey-overview.pdf.

O'Halpin, Eunan. 1999. Defending Ireland: The Irish State and its Enemies. Oxford: Oxford University Press.

O'Malley, Eoin, and Shane Martin. 2010. The Government and the Taoiseach. In John Coakley and Michael Gallagher (eds). Politics in the Republic of Ireland. 5th edn. Abingdon: Routledge, pp. 295-326.

Opheim, Cynthia. 1991. Explaining the Differences in State Lobby Regulations. The Western Political Quarterly, 44:2, pp. 405-21.

Ortega, J. 2014.'Lobbying in Mexico'. Presentation to OECD, Paris. www.slideshare .net/OECD-GOV/5-jorge-ortega-lobbying-in-mexico-jorge-ortega.

Ozymy, J. 2013. Keepin' on the Sunny Side: Scandals, Organized Interests and the Passage of Legislative Lobbying Laws in the American States. American Politics Research, 41:1, pp. 3-23.

Papandrea, Mary-Rose. 2014. Leaker Traitor Whistleblower Spy: National Security Leaks and the First Amendment. Boston University Law Review, 94:2, pp. 449-544.

Parker, David. 2006. Enterprise Sales: Thatcher Leads the Charge. In Graeme A. Hodge (ed.). Privatization and Market Development: Global Movements in Public Policy Ideas. Cheltenham: Edward Elgar, pp. 9-35.

Pateman, Carol. 1976. Participation and Democratic Theory. Cambridge: Cambridge University Press.

Piasecka, A. 2007. Lithuania. Washington, DC: Freedom House.

Piasecka, Aneta. 2006. Country Report: Lithuania (2006). Washington, DC: Freedom House. Available at: www.freedomhouse.org/template.cfm?page $=47 \&$ nit=394\&year=2006.

Piasecka, Aneta. 2007. Country Report: Lithuania (2007). Washington, DC: Freedom House. Available at: www.freedomhouse.org/template.cfm?page $=47 \&$ nit $=428$ \&year $=2007$.

Piasecka, Aneta. 2008. Lithuania. In Nations in Transit 2008. Washington, DC: Freedom House, pp. 363-85. Available at: www.freedomhouse.hu/images/ fdh_galleries/NIT2008/NTLithuania-final.pdf.

Pieczka, M. 2006. 'Chemistry' and the Public Relations Industry: An Exploration of the Concept of Jurisdiction and Issues Arising. In J. L'Etang and M. Pieczka (eds). Public Relations: Critical Debates and Contemporary Practice. London: Lawrence Erlbaum Associates, Publishers, pp. 303-32.

Popper, Karl. 1963. Conjectures and Refutations: The Growth of Scientific Knowledge. London: Routledge.

Public Relations Institute of Ireland. 2003. Code of Professional Practice for Public Affairs \& Lobbying. Public Relations Institute of Ireland: Dublin. Available at: www.prii.ie/show_content.aspx?idcategory=1\&idsubcategory=1\#PRRIICode.

Putnam, Robert D. 1988. Diplomacy and Domestic Politics: The Logic of Two-level Games, International Organization, 42:3, pp. 427-60.

Rakowski, Piotr, and Robert Rybicki. 2000. Features - An Overview of Polish Law. Law and Technology Resources for Legal Professionals. Available at: www.llrx.com/features/polish.htm. 
Razin, Eran, 2013. Councillors and their Parties. In Bjorn Egner, David Sweeting and Pieter-Jan Klok (eds). Local Councillors in Europe. Wiesbaden: Springer VS, pp. 51-62.

Rechtman, Rene. 1998. Regulation of Lobbyists in Scandinavia - A Danish Perspective. Parliamentary Affairs, 51:4, pp. 579-86.

Regulski, Jerzy. 2003. Local Government Reform in Poland: An Insider's Story, Budapest: Open Society Institute.

Risse, Thomas. 2000. 'Let's Argue!' Communicative Action in World Politics. International Organization, 54:1, pp. 1-39.

Rocco, P. and C., Thurston. 2014. From Metaphors to Measures: Observable Indicators of Gradual Institutional Change. Journal of Public Policy, 34:1, pp. 35-62.

Rodríguez Fiss, H., and C. S. Thomas. 2014. The Chilean Big Business Lobby: A Long-standing and Major Influence on Public Policy. Journal of Public Affairs, 14:3, pp. 310-30.

Rogers, M. Z., and N. Weller. 2014. Income Taxation and the Validity of State Capacity Indicators. Journal of Public Policy, 34:2, pp. 183-206.

Rogers, R. E. 1969. Max Weber's Ideal Type Theory, New York: Philosophical Library.

Ronit, Karsten, and Volker Schneider. 1998. The Strange Case of Regulating Lobbying in Germany. Parliamentary Affairs, 51:4, pp. 559-67.

Rooduijn, M., and T. Pauwels. 2011. Measuring Populism: Comparing Two Methods of Content Analysis. West European Politics, 34:6, pp. 1272-83.

Roper, Steven D. 2002. Are All Semipresidential Regimes the Same? A Comparison of Premier-Presidential Regimes. Comparative Politics, 34:3 (April), pp. 253-72.

Rosenberg, J. 2001. Mexico, the End of Party Corporatism? In C. S. Thomas (ed.). Political Parties and Interest Groups: Shaping Democratic Governance. Overseas Development Council: Washington, DC.

Rosenson, B. A. 2003. Against Their Apparent Self-Interest: the Authorization of Independent State Legislative Ethics Commissions, 1973-96. State Politics and Policy Quarterly, 3:1, pp. 42-65.

Rosenson, A. B. 2005. The Shadowlands of Conduct: Ethics and State Politics. Washington, DC: Georgetown University Press.

Rosenthal, A. 2001. The Third House: Lobbyists and Lobbying in the States. Washington, DC: Congressional Quarterly.

Ross, Robert. 2000. The 1995-1996 Taiwan Strait Confrontation: Coercion, Credibility, and Use of Force. International Security, 25:2, pp. 87-123.

Rush, Michael. 1998, The Canadian Experience: The Lobbyists Registration Act. Parliamentary Affairs, 51:4, pp. 516-23.

Ryan, S. 2008. MPs Escape Scrutiny by Lobbyist Code. The Australian, 3 April.

Sachs, Jeffery. 1990. What is to be Done? The Economist, 14 January, pp. 19-24.

Sahd, J., and C. Valenzuela. 2017. Lobby Regulation in Chile: A Pathway Toward Reducing Inequality. Presented at the 2017 OECD Global Ant-Corruption and Integrity Forum.

Sallé D., and F. Marchi. 2017. France. In A. Bitonti and P. Harris (eds). Lobbying in Europe. Palgrave Macmillan, pp. 255-62. 
Sanchez Salgado, R. 2014. Rebalancing EU Interest Representation? Associative Democracy and EU Funding of Civil Society Organizations. JCMS: Journal of Common Market Studies, 52:2, pp. 337-53.

Scharpf, Fritz W. 2003. Problem-Solving Effectiveness and Democratic Accountability in the EU. MPIfG Working Paper (03/01, 2003).

Schedler, Andreas. 1999. Conceptualising Accountability. In Andreas Schedler, Larry Diamond and Marc F. Plattner (eds). The Self-Restraining State: Power and Accountability in New Democracies. London: Lynne Rienner, pp. 13-29.

Schmitter, P. C. 1974. Still the Century of Corporatism? The Review of Politics, 36:1, pp. 85-131.

Schubert, L., T. R. Dye and H. Zeigler. 2016. The Irony of Democracy: An Uncommon Introduction to American Politics. Wadsworth Publishing.

Scott, J. C. 2015. The Social Process of Lobbying: Cooperation of Collusion? New York, NY: Routledge.

Scott, Colin. 2000. Accountability in the Regulatory State. Journal of Law and Society, 27:1, pp. 38-60.

Seawright, J., and D. Collier. 2014. Rival Strategies of Validation: Tools for Evaluating Measures of Democracy. Comparative Political Studies, 47:1, pp. 111-38.

Sekuless, P. 1991. Lobbying Canberra in the Nineties. Sydney: Allen \& Unwin.

Serrill, Michael S. 1990. Soviet Union War of Nerves. Time International, 2 April.

Siaroff, Alan. 1999. Corporatism in 24 Industrial Democracies: Meaning and Measurement. European Journal of Political Research, 36:6, pp. 175-205.

Smyth, Jamie. 2006. EU Proposes Voluntary Registration for Lobbyists. The Irish Times, 4 May.

Soukeník, Š., M. Gregor and A. Matušková. 2017. Czech Republic. In A. Bitonti and P. Harris (eds). Lobbying in Europe: Public Affairs and the Lobbying Industry in 28 EU Countries. London: Palgrave Macmillan.

Stark A. 1992. Political Discourse Analysis and the Debate over Canada's Lobbying Legislation. Canadian Journal of Political Science, 25:3, pp. 513-34.

Stasavage, David. 2003. Transparency, Democratic Accountability, and the Economic Consequences of Monetary Institutions. American Journal of Political Science, 47:3, pp. 389-403.

Stasavage, David. 2004. Open-Door or Closed-Door? Transparency in Domestic and International Bargaining. International Organization, 58:4, pp. 667-703.

Streeck, W., and P. C. Schmitter. 1991. From National Corporatism to Transnational Pluralism: Organized Interests in The Single European Market. Politics and Society, 19:3, pp. 133-64.

Subramaniam, V. 1983. Public Accountability: Context, Career and Confusion of a Concept. Indian Journal of Public Administration, 29:3, pp. 446-56.

Suleiman, E. N. 2015. Politics, Power, and Bureaucracy in France: The Administrative Elite. Princeton University Press.

Szary, Wiktor, and Pawel Florkewicz. 2015. Thousands March Against Polish Government as Constitutional Spat Drags on. Reuters, 12 December. Available at: www.reuters.com/article/us-poland-protests-idUSKBN0TV0PW20151213.

Tal, H. 2009. The Commercial Lobby in Israel - the Factors of its Growth and the Ways of its Action. Bar Ilan University: Ramat Gan.

Tal, H. 2012. Regulating Lobbying Activity in Israel. Percorsi Costituzionali, 3, pp. 153-63. 
Thatcher, M. 2002. Regulation After Delegation: Independent Regulatory Agencies in Europe. Journal of European Public Policy, 9:6, pp. 954-72.

Thatcher, M. 2005. The Third Force? Independent Regulatory Agencies and Elected Politicians in Europe. Governance, 18:3, pp. 347-73.

Thomas, Clive S. 1998. Interest Group Regulation Across the United States: Rationale, Development and Consequences. Parliamentary Affairs, 51:4, pp. 500-15.

Thomas, Clive S. 2004. Lobbying in the United States: An Overview for Students, Scholars and Practitioner. In Phil Harris and Craig S. Fleischer (eds). The Handbook of Public Affairs. London: Sage Publications Ltd.

Thomas Clive S., and Ronald Hrebenar. 1996. Regulating Interest Groups in the United States: National, State and Local Experiences. Paper prepared for presentation at annual meeting of the American Political Science Association, San Francisco, California, 5-8 September.

Thomas, C. S., and K. Klimovich. 2014. Power Groups, Interests and Interest Groups in Latin America: A New Era or More of the Same? Journal of Public Affairs, 14:3-4, pp. 392-422.

Tognato, Carlo. 2012. Central Bank Independence: Cultural Codes and Symbolic Performance. New York, NY: Palgrave Macmillan.

Toledano, Margalit. 2012. Practice of Public Relations in Israel. In Robert L. Heath (ed.). Encyclopaedia of Public Relations. Thousand Oaks, CA: Sage, pp. 491-3.

Transparency International. 2006. Report on the Transparency International Global Corruption Barometer 2006. Berlin: International Secretariat, Transparency International. Available at: http://archive.transparency.org/policy_research/surveys_ indices/gcb/2006.

Transparency International. 2011. The Global Corruption Barometer. Available at: www.transparency.org/gcb201011/in_detail.

Transparency International. 2014a. Lifting the Lid on Lobbying: France. Available at: www.transparency-france.org/wp-content/uploads/2016/04/Rapport-Lobbyingen-France_Octobre-2014.pdf (accessed 23 October 2017).

Transparency International. 2014b. Lifting the Lid on Lobbying: Slovenia. Available at: www.transparency.si/images/publikacije/lobiranje/report_lobbyinginslovenia.pdf

Transparency International. 2015a. Accountable Influence: Bringing Lobbying out of the Shadows. London: Transparency International UK.

Transparency International. 2015b. Lifting the Lid on Lobbying: The Netherlands. Available at: http://lobbywatch.nl/wp-content/uploads/2016/12/Lifting-the-Lidon-Lobbying-Enhancing-Trust-in-Public-Decision-making-in-the-Netherlands. pdf.

Trommer, S., and R. Chari. 2006. The Council of Europe: Interest Groups and Ideological Missions? West European Politics, 29:4, pp. 665-86.

Tusinski-Berg, Kati. 2009. Lobbying as Advocacy Public Relations and its 'Unspoken' Code of Ethics. In Conor McGrath (ed.). Interest Groups and Lobbying: Volume One - The United States, and Comparative Studies. Lewiston: Edwin Mellen Press, pp. 135-56.

Van Biezen, I., P. Mair and T. Poguntke. 2012. Going, going ... Gone? The Decline of Party Membership in Contemporary Europe. European Journal of Political Research, 51:1, pp. 24-56.

Van Keulen, P. J. G. 2017. The Netherlands. In A. Bitonti and P. Harris (eds). Lobbying in Europe. Palgrave Macmillan, pp. 255-62. 
Vandekerckhove, W., and D. Lewis. 2011. Whistleblowing and Democratic Values. 1 st edn. The International Whistleblowing Research Network. Available at: www.academia.edu/1348441/Whistleblowing_and_Democratic_Values_free_ ebook.

Vargovčíková, J. 2015. Professional Lobbyists as Representative Claim-makers. The Cases of Poland and the Czech Republic. Human Affairs, 25:2, pp. 142-52.

Vargovčíková, J. 2017. Inside Lobbying Regulation in Poland and the Czech Republic: Negotiating Public and Private Actors' Roles in Governance. Interest Groups and Advocacy, 6:3, pp. 253-71.

Veksler, A. 2012. Opaque Transparency: An Analysis of the Israeli Lobbying Regulatory Regime of 2008. Journal of Public Affairs, 12:4, pp. 270-8.

Veksler, A. 2015. Diluted Regulations: A Need to Review the Theoretical Classification of the Different Lobbying Regulatory Environments. Journal of Public Affairs, 15:1, pp. 56-64.

Veksler, Albert. 2016. Lobbying in the Sunshine - Hiding Behind Transparency? Journal of Public Affairs, 16:1, pp. 39-49.

Verčič, D., and A. T. Verčič. 2012. Public Relations and Lobbying: New Legislation in Slovenia. Public Relations Review, 38:1, pp. 14-21.

Visser, J., and A. Hemerijck. 1997. A Dutch Miracle: Job growth, Welfare Reform and Corporatism in the Netherlands. Amsterdam: Amsterdam University Press.

Visser, J. 2016. Database on Institutional Characteristics of Trade Unions, Wage Setting, State Intervention and Social Pacts, 1960-2014 (ICTWSS). University of Amsterdam. Available at: http://uva-aias.net/en/ictwss (accessed 29 May 2018).

Wallerstein, M., and B. Western. 2000. Unions in Decline? What has Changed and Why. Annual Review of Political Science, 3:1, pp. 355-77.

Wang, Flora. 2008. Civic Groups Call for Amendments to Lobbying Act. Taipei Times, 9 August. Available at: www.taipeitimes.com/News/taiwan/archives/2008/08/ 09/2003419819.

Ward, Alan J. 1999. Australian Parliamentary Orthodoxy: A Foreign Perspective on Australian Constitutional Reform. Lecture in the Senate Occasional Lecture Series at Parliament House on 18 June. Available at: www.aph.gov.au/SEnate/ pubs/pops/pop35/c04.htm.

Ward. Alan J. 2014. Parliamentary Government in Australia. London: Anthem Press.

Warhurst, John. 1998. Locating the Target: Regulating Lobbying in Australia. Parliamentary Affairs, 51:4, pp. 538-50.

Warhurst, John. 2008. The Lobbying Code of Conduct: An Appraisal. Democratic Audit Discussion Paper 4/08. Available at: http://arts.anu.edu.au/democraticaudit/ categories/incumb_benfrm.htm.

Warhurst, John. 2014. Interest Groups and Political Lobbying. In Alan Fenna, Jane Robbins and John Summers (eds). Government Politics in Australia. Fenchs Forest: Pearson Australia, pp. 259-74.

Warren, S. 2011. The Social Potential of GIS. In Timothy L Nyerges, Helen Couclelis and Robert McMaster (eds). The SAGE Handbook of GIS and Society. London: SAGE Publications.

Wasilewski, Patryk, and Marcin Sobczyk. 2013. Poland's Economy Slows Sharply. The Wall Street Journal, 14 May. Available at: http://blogs.wsj.com/ emergingeurope/2013/05/14/polands-economy-slows-sharply. 
Watson R., and M. Shackleton. 2003. Organized Interests and Lobbying in the EU. In Elizabeth Bomberg and Alexander Stubb (eds). The EU: How Does it Work? Oxford: Oxford University Press, pp. 88-107.

Weber, M. 1978 [1904]. Economy and Society. Edited by G. Roth and C. Wittich. Berkeley: University of California Press.

Weller, Patrick, and Jenny Fleming. 2003. The Commonwealth. In Jeremy Moon and Campbell Sharman (eds). Australian Politics and Government. Cambridge: Cambridge University Press, pp. 12-40.

Wiessala, G. 1999. European Union in a Changing World - Trompe l'oeil or Revolution? Reform of the European Commission on the Eve of 2000. World Affairs, 3:4.

Williams, Andy. 1998. UK Government and Politics. 2nd edn. Oxford: Heinemann.

Wilson, F. L. 1983. French Interest Group Politics: Pluralist or Neocorporatist? American Political Science Review, 77:4, pp. 895-910.

Wilson, William T. 2014. Market Solutions Should Be Central to U.S.'s Taiwan Policy. The Heritage Foundation. 1 August. Available at: http://www.heritage.org/research/ reports/2014/08/market-solutions-should-be-central-to-uss-taiwan-policy.

Wiszowaty, Marcin Michal. 2010. Lobbying Act and the Law-making Process. The Sejm Review, 4th special edn, pp. 151-82.

Witko, C. 2007. Explaining Increases in the Stringency Of State Campaign Finance Regulation, 1993-2002. State Politics \& Policy Quarterly, 7:4, pp. 369-93.

Woldendorp, J., and H. Keman. 2007. The Polder Model Reviewed: Dutch Corporatism 1965 - 2000. Economic and Industrial Democracy, 28:3, pp. 317-47.

Woll, C. 2012. The Brash and the Soft-spoken: Lobbying Styles in a Transatlantic Comparison. Interest Groups \& Advocacy, 1:2, pp. 193-214.

Wolpe, Bruce C., and Bertram J. Levine. 1996. Lobbying Congress: How the System Works. Washington, DC: CQ Press.

Worthy, B. 2017. The Politics of Freedom of Information: How and Why Governments Pass Laws That Threaten Their Power. Manchester: Manchester University Press.

Wyrzykowski, Miroslaw, and Agnieszka Cielen. 2006. Presidential Elements in Government Poland - Semi-presidentialism or 'Rationalised Parliamentarianism?’ European Constitutional Law Review, 2:2, pp. 253-67.

Yishai, Y. 1987. Interest Groups in Israel: The Test of Democracy. Tel Aviv: Am Oved (in Hebrew).

Yishai, Yael. 1991. Land of Paradoxes: Interest Politics in Israel. Albany, NY: State University of New York Press.

Yishai Y. 1998. Regulation of Interest Groups in Israel. Parliamentary Affairs, 51:4, pp. 568-78.

Yishai Y. 2009. Interest Group Strategies: An Institutional View from Israel. In C. McGrath (ed.). Interest Groups and Lobbying in Latin America, Africa, The Middle East, and Asia. Lewiston: The Edwin Mellen Press, pp. 219-39.

Yoder, Jennifer. 2007. Leading the Way to Regionalization in Post-Communist Europe: An Examination of the Process and Outcomes of Regional Reform in Poland. East European Politics and Society, 21:3, pp. 424-46.

Young, I. M. 2002. Inclusion and Democracy. Oxford: Oxford University Press.

Zeller B. 1958. Regulation of Pressure Groups and Lobbyists. Annals of the American Academy of Political and Social Sciences, 319, pp. 94-103. 
Zetter, L. 2014. Lobbying: The Art of Political Persuasion. 3rd edn. Petersfield: Harriman House Ltd.

Žiliukaite, Ruta, Aiste Ramonaite, Laima Nevinskaite, Vida Beresnevičiute and Inga Vinogradnaite. 2006. Neatrasta galia: Lietuvos pilietines visuomenes žemelapis (Undiscovered Power: Map of the Civil Society in Lithuania). Vilnius: Civil Society Institute. Conclusion available in English at: www.civitas.lt/files/ Project_MapOfCivilSociety_Conclusiosns.pdf [sic].

Zrahiyah, Z. 2008. The People Who Raise the Knesset Members' Hands. Ha'aretz, 10 July. Available at: www.haaretz.com/1.5001305 (accessed 2 January 2009). 